\title{
O mal, A matéria e a Lei em Moisés Maimônides
}

\author{
Cecilia Cintra Cavaleiro de Macedo ${ }^{1}$
}

\begin{abstract}
Resumo: Moisés Maimônides (1135-1204) é um dos mais importantes pensadores medievais. Sua obra filosófica o Guia dos perplexos não apenas se tornou uma referência fundamental para os pensadores judeus até os dias atuais, mas também exerceu intensa influência sobre os autores latinos durante a escolástica cristã. O Guia aborda diversos temas, dentre eles, há a questão do mal. Maimônides não acredita na existência de um mal substancial. Sem estatuto ontológico próprio, o mal é meramente privação do bem e se divide em três classes: mal natural, o mal que um homem inflige a outro ou aos demais em geral e aquele mal que o homem causa a si mesmo. Este artigo visa expor a perspectiva racionalista de Maimônides sobre a questão do mal e a fundamentação desta na matéria, a importância da Lei, bem como sua consequente proposta de conduta ética.
\end{abstract}

Palavras-chave: Maimônides. Mal. Matéria. Lei. Intelectualismo ético.

\section{INTRODUÇÃo}

Moisés Maimônides é, sem dúvida, o mais conhecido representante da filosofia judaica na Idade Média. Tendo vivido entre 1135 e 1204, é um dos mais importantes pensadores medievais, não somente por ser uma referência fundamental para os pensadores judeus até os dias atuais, mas também pela intensa influência que exerceu na escolástica cristá. Filósofo, estudioso do Talmud e médico de formação, sua principal obra filosófica é o Guia dos perplexos, escrita originariamente em árabe, sob o título Dalalat al-'airin. Esta obra foi composta em três partes e discorre sobre os mais variados assuntos de interesse da filosofia e teologia da época, desde as questóes de interesse mais propriamente religioso, como a profecia e os atributos ${ }^{2}$ de Deus, até alguns

\footnotetext{
1 Professora do Departamento de Filosofia e do Programa de Pós-Graduação em Filosofia da Universidade Federal de São Paulo (Unifesp), Guarulhos, SP - Brasil. (D) https://orcid.org/00000002-8321-6944 E-mail: ceciliacmcavaleiro@gmail.com

2 Problema este que persegue o pensamento filosófico judaico desde Filon de Alexandria. Para maior detalhamento do tema em Maimônides, ver Verza (1999).
}

http://dx.doi.org/10.1590/0101-3173.2019.v42esp.10.p171

This is an open-access article distributed under the terms of the Creative Commons Attribution License. 
temas de preocupação nitidamente filosófica, como a teoria aristotélica da eternidade do universo. Em termos da sua participação na comunidade judaica, Maimônides chegou a ser nagid (líder) da comunidade judaica do Cairo. Escreveu várias obras também no campo mais propriamente religioso judaico, que são consideradas fundamentais para a reflexão sobre a religião e cujo estudo é imprescindível até hoje nos programas de formação dos seminários teológicos judaicos. Dentre estas obras, merecem destaque especial a Mishne Torah, que se dedica à interpretação da lei, sendo também um condensado de jurisprudência judaica. São parte desta obra seus comentários aos 613 preceitos e às Leis da Torah (Pentateuco), que Maimônides irá tentar condensar em seus célebres 13 preceitos; também fundamental é seu comentário à Mishná, escrito em árabe sob o título Kitab al-Siraj, além de diversas epístolas. Em sua atuação profissional enquanto médico, foi respeitado e até célebre, chegando a servir na corte do sultáo Salah Al-Din (Saladino). Também neste campo nos legou diversas obras importantíssimas que influenciaram toda a medicina medieval e figuram até hoje na história da medicina.

\section{O Pensamento de Maimônides E os ObJetivos do Guia dos PERPLEXos}

De acordo com as proposiçôes do próprio autor, seu objetivo principal e razão primeira que impulsiona o esforço de Maimônides ao escrever o Guia dos perplexos é o esclarecimento de pontos obscuros da Bíblia e, através disso, "expor explicitamente o verdadeiro sentido de seus fundamentos, encobertos à inteligência do povo". Com este intuito, indica que sua primeira intenção teria sido a de explicar "certos termos que aparecem nos livros proféticos". Como sabemos, as passagens bíblicas que relatam em especial as visóes recebidas pelos profetas se incluem entre as partes mais obscuras e são objetos de interpretação e contemplação da mística judaica através dos tempos. Mas, além desta, indica uma segunda intenção para sua obra, explicada como sendo a de:

Explicar certas figuras obscuras que estão nos livros proféticos, mas, que não são propriamente caracterizadas como tais. Ignorantes e leitores superficiais as tomaram no sentido literal e não no sentido figurado. Mesmo aqueles bem informados ficam perplexos ao tomarem estas passagens em sua significação literal, mas ficam totalmente aliviados desta perplexidade ao explicitarmos a figura, ou meramente sugerirmos que os termos são figurativos. (Guia I, introduçãó ${ }^{3}$ ).

\footnotetext{
${ }^{3}$ As citaçóes de trechos do Guia dos perplexos estarão indicadas simplesmente com o termo Guia, a parte na qual se encontra o trecho contará em algarismos romanos e o capítulo em algarismos arábicos.
} 
Vemos que já nessa passagem ele se refere à perplexidade que acometeria mesmo certos estudiosos ao tentarem interpretar as passagens em sentido literal. Daqui temos, por certo, o título do livro. Essa perplexidade referida pelo autor consistiria no estupor causado pela tentativa de interpretaçáo literal de passagens bíblicas, principalmente, se consideradas à luz da especulação lógico-racional. Consideradas de difícil compreensão, senão impossível, Maimônides advoga ser esta reaçáo provocada pela linguagem utilizada nas Escrituras, que, diante de uma leitura simples e submetida a uma compreensão literal, se mostram até mesmo absurdas. A partir desta constatação, o autor se propóe a auxiliar a compreensão dessas passagens por intermédio do recurso à interpretação figurativa e simbólica, o que esclareceria seu sentido originário.

Podemos dizer que desse esforço de Maimônides se depreende uma verdadeira filosofia da linguagem bíblica, posto que sua reflexão sobre a linguagem se mostra profunda e cuidadosa. Embora não possamos dizer que a interpretação alegórica seja sua interpretação preferencial quando da exegese geral ou de passagens que possam ser entendidas de modo literal ou com recurso mínimo à interpretação simbólica, como temos em Filon de Alexandria, ele se utiliza desses recursos quando necessário. Vale salientar que é fundamental em sua obra a proposta de que as Escrituras estão repletas de termos equívocos ou polivalentes. Ele utiliza muito o recurso à atribuição de homonímia, através do qual o autor advoga que certos termos que, na linguagem usual, se referem a coisas concretas e sensíveis ou a açôes humanas e que ocorrem no espaçotempo, ao serem encontrados em referências a Deus ou às realidades superiores, são utilizados por aproximação. Esta aproximação ocorre em virtude de uma extensão inexata de seu significado, mas jamais por coincidência completa com seu significado corrente quando aplicadas ao mundo sensível. Assim, de certa maneira, Maimônides se aproxima da defesa de uma teologia negativa, uma vez que, em uníssono com as correntes principais do pensamento judaico, nega a possibilidade de que a linguagem humana seja suficiente para qualquer referência apropriada às realidades superiores.

Profundamente inserido no esforço geral da filosofia medieval, quer dizer, na linha de compatibilização entre a mensagem revelada e a especulação

A versão em idioma moderno mais utilizada foi a tradução ao inglês de Friedlander, que aqui seguimos preferencialmente. Vale ressaltar a tradução do texto completo ao espanhol por David Gonzalo Maeso, sob o título de Guía de perplejos, eventualmente mais acessível ao leitor brasileiro e da traduçáo das duas primeiras partes ao português por Uri Lam. Recentemente, em 2018, houve a publicação do texto completo do Guia dos perplexos, embora tenha sido por uma editora que costuma apresentar um viés religioso em suas publicaçóes. 
racional humana, uma das grandes preocupaçôes que Maimônides apresenta em sua obra é em relaçáo ao esclarecimento de diversas aparentes contradiçóes entre a mensagem bíblica e a filosofia racional. Para ele, estas contradiçóes, em sua grande maioria, não passam de aparência, pois as diferenças residem somente na linguagem. As supostas contradiçôes derivariam das diferenças profundas observadas na terminologia utilizada. Mas isso náo indicaria contradição ou alguma incompatibilidade radical, uma vez que, como já mencionamos, a linguagem não seria capaz de designar diretamente as realidades que ultrapassam o mundo sensível e extenso no tempo e no espaço e muitos termos seriam, portanto, utilizados na linguagem bíblica em sentido negativo, para afastar-se de um significado contrário, ou por uma grosseira aproximação com o sensível.

Ele ensina verdades filosóficas sem impedir o compromisso religioso, mostrando que a filosofia náo necessita romper normas sociais ou destruir crenças religiosas. A religiáo leva as verdades abstratas da filosofia na forma de imagens e símbolos, Maimônides argumenta, mas a religião não é meramente uma representação mítica das verdades racionais, ela também leva até onde a ciência encontra seus limites. (KRAEMER, 2005, p.43).

Maimônides considera possível iluminar os pontos obscuros das Escrituras através de suas explicaçóes sobre a linguagem e mostrar que as idéias expressas nos textos que são o objeto da fé judaica, ao serem lidos a partir de uma perspectiva não tão literal, se apresentam tão plausíveis quanto quaisquer outras teorias concorrentes, e mesmo, em diversas questóes, seu conteúdo revelado não se opóe aos resultados da especulação racional. Por estes objetivos e explicações do autor, vemos que o Guia não consiste em obra fácil ou de compreensão simples, mas é dedicada àqueles que já possuem conhecimentos prévios advindos tanto da tradição religiosa quanto da literatura filosófica.

Em suma, a obra não é dirigida nem aos filósofos nem tampouco aos desprovidos de toda formação intelectual, mas ao círculo de estudiosos que se encontram desconcertados por certos problemas que aparentam contradiçáo entre religião e filosofia, ou simplesmente a razão natural, extremos estes que o Guia dos perplexos propóe conciliar. (MAESO, 2008, p. 15).

Assim, se Maimônides se revela, por um lado, um autor profundamente versado na filosofia de seu tempo e um dedicado estudioso e admirador das 
obras de Aristóteles ${ }^{4}$, paralelamente a isso, vemos que se trata igualmente de alguém intimamente imbuído da fé judaica. Além de praticante e estudioso ele mesmo, já fora educado desde cedo na discussão talmúdica, para a qual teve importantes mestres, incluindo seu próprio pai. Portanto, ainda que se utilize amplamente da linguagem, da lógica e de materiais advindos da filosofia grega, Maimônides mantém seu foco na temática original proveniente das questóes propostas pela fé judaica. Assim, podemos considerá-lo propriamente um filósofo judeu e seus escritos no âmbito do que se convencionou chamar de filosofia do judaísmo5 .

Maimônides nos mostra ser um pensador essencialmente racionalista. Mas, este seu racionalismo está longe de conduzi-lo a uma negação de sua fé. Muito pelo contrário, assim como sua temática, o desenvolvimento de seu pensamento é radicado fortemente na própria tradição teológica rabínica, caracterizada pelas discussōes talmúdicas, nas quais a razão figura como um instrumento conferido por Deus ao homem para a interpretação da mensagem bíblica. É este tipo de racionalismo teológico, já amplamente utilizado na época pelos mutakallimin, que caracterizará também sua apreciação filosófica. Dele decorrerão os paralelos que traça entre diversas questóes contidas no texto bíblico com as noçóes filosóficas de sua época, sugerindo a compreensão de uma série de conceitos filosóficos a partir daqueles que entende como seus equivalentes revelados. Por exemplo, Maimônides tenta aproximar o modelo emanacionista com a crença na criação, a partir do entendimento da processão dos neoplatônicos, ou seja, o processo de surgimento das diversas realidades a partir do Uno, como emanaçáo divina, equivalente, por sua vez, ao conceito hebraico de Shefa. Este último termo pode ser traduzido literalmente por abundância, mas é aplicado por extensão à influência de Deus no mundo ${ }^{6}$. As

\footnotetext{
${ }^{4}$ Observe-se que aqui nos referimos ao Aristóteles conhecido na Idade Média, ou seja, contam-se entre suas obras as atribuiçôes arbitrárias, e lido a partir de comentadores. "Aristóteles encabeça a lista de autoridades filosóficas que Maimônides admira e cita ou parafraseia frequentemente. No entanto, como ele diz a Samuel [Samuel ibn Tibbon, tradutor de seus livros ao hebraico], Aristóteles precisa ser estudado com seus comentários, especificamente, aqueles de Alexandre de Afrodísia, Temistio ou Averróis." (IVRY, 2005, p. 59).

5 Para esta discussão ver Guttmann, que defende que a filosofia judaica possui traços próprios, uma vez que sua temática provém de questionamentos internos à religião e não de investigações metafísicas racionais. "Desde a Antiguidade, a filosofia judaica foi essencialmente uma filosofia do judaísmo. Mesmo na Idade Média - que conheceu algo como uma total e abrangente cultura baseada na religiáo - ela raras vezes transcendeu o seu centro religioso." (GUTTMANN 2003, p. 28).

${ }^{6}$ A doutrina da criação expressa através da emanação pode ser identificada já nos primeiros escritos filosóficos islâmicos, como nos tratados dos Irmãos da Pureza e em Al Kindi, como uma adaptação da
} 
inteligências separadas, provenientes do modelo aristotélico, são equiparadas por ele às entidades angelicais.

Assim, seu aristotelismo e, consequentemente, sua adesão à filosofia em geral é sempre, de certo modo, limitado pelas Escrituras e contextualizado por sua fé, no sentido de que o autor toma para si exclusivamente aqueles conteúdos filosóficos que podem ser lidos a partir de um referencial bíblico e apresentam, de alguma forma, equivalentes no conteúdo da palavra revelada. Já quanto àquelas questôes que se opóem frontalmente à fé mosaica, Maimônides não só discorda veementemente delas, como não poupa esforços para desacreditá-las. Ele se esforça por apresentá-las como teorias jamais demonstradas e defendendo que aquelas teorias filosóficas que não foram demonstradas devidamente, ou seja, a seu ver, todas aquelas que se referem às realidades supra-sensíveis, não passam de meras opiniōes como quaisquer outras, apoiadas muitas vezes em argumentos de autoridade, mediante recurso a filósofos anteriores. Desse modo, nada garantiria sua superioridade frente à palavra revelada pelos profetas, uma vez que se trata de escolha entre crenças igualmente apoiadas em argumentos de autoridade.

Esse é o caso de sua exposição da controversa questão da idéia de criação a partir do nada versus a teoria da eternidade do mundo, talvez a mais célebre controvérsia que Maimônides sustenta contra o aristotelismo ${ }^{7}$. Utilizando-se da própria terminologia aristotélica e argumentação lógica e mantendo-se sempre estritamente no âmbito da especulação racional filosófica, aponta que a eternidade do mundo defendida por Aristóteles é uma teoria que carece de demonstraçáo apropriada, não podendo ser tomada como verdadeira, uma vez que jamais foi comprovada. E mais: afirma que o próprio Aristóteles estaria plenamente consciente disso, uma vez que acaba por apelar para argumentos de autoridade e, contrariando suas próprias idéias sobre a demonstração, desenvolve diversas argumentações diferentes para tentar estabelecer sua posição e convencer adversários ${ }^{8}$. Maimônides utiliza as

perspectiva neoplatônica, especialmente plotiniana. "A dívida de Maimônides a esta perspectiva é refletida em sua visão de Deus, bem como na emanação, matéria e Divina Providência." (IVRY, 2005, p. 63).

${ }^{7}$ Sobre a explanaçáo do tema por Maimônides já escrevi em outra ocasião. Ver Cavaleiro de Macedo (2009).

${ }^{8}$ Se algum [dos argumentos apresentados\} constitui uma demonstraçáo, não haveria necessidade de confiar em outros. Note-se que não são encontrados múltiplos argumentos em Euclides: uma vez que um teorema é provado, o problema é encerrado. Em contraste, quanto mais argumentos alguém oferece, maior é a dúvida de que qualquer deles seja válido. Se nenhum é válido, o modo do argumento não é demonstrativo, mas dialético. Nos Tópicos, Aristóteles mesmo cita a eternidade do mundo como um exemplo clássico de questão que deve ser decidida dialeticamente. (SEESKIN, 2005, p. 196). 
dificuldades apresentadas pela determinação do movimento dos planetas e das esferas, bem como a especulação acerca da constituição destes, para apontar que, longe de resolver a questão, a teoria aristotélica apresenta mais dúvidas e questôes em aberto do que sua concorrente bíblica. Defende, desse modo, que a teoria bíblica da criação, ainda que tampouco possa ser comprovada por meios racionais, suscita menos problemas que a eternidade aristotélica.

Ainda nos moldes do aristotelismo medieval neoplatonizado, lido a partir dos cânones judaicos, Maimônides afirma que a filosofia - entendida aqui como ciência da época - é o instrumento perfeito para o estudo da realidade sensível, sujeita à geração e corrupção, ou seja, para o mundo sublunar, mas somente para este âmbito. As realidades superiores, celestes ou inteligíveis são inatingíveis pela inteligência puramente humana, não podendo ser alvos da especulação racional. E vai além, na esteira do que se estabelece no Talmud, estendendo esta idéia até a astronomia, já que afirma que especular sobre as esferas celestes chega a ser mesmo uma insanidade. Se, baseando-se no modelo de Aristóteles, a matéria sensível sujeita à geração e corrupção só ocorre no mundo sublunar, e, portanto, as esferas celestes náo estáo sujeitas a estes processos, dado que seu movimento é mais perfeito, circular e eterno, Maimônides entende a astronomia também no escopo daquelas verdades que somente Deus é capaz de conhecer. A partir disso, o que se tenta estabelecer em termos de conhecimento acerca do céu não passaria de especulação, posto que não somente seria inalcançável pelo intelecto humano, como também uma atividade considerada proibida aos homens comuns pela fé judaica'. Ele segue aqui o pensamento encontrado na Mishná que afirma: "Quem quer que tenha especulado sobre estas quatro coisas, melhor seria que não tivesse vindo ao mundo: o que há acima? O que há abaixo? O que era antigamente? O que será doravante?” (Mishna Haguigá, 2:1 apud GUTTMANN, 2003, p. 64). Assim, Maimônides considera a especulação sobre as esferas no mesmo plano em que estariam as artes divinatórias em geral. E se exprime sobre o assunto no Guia dos perplexos da seguinte maneira:

Com respeito ao mundo celeste, o homem tudo ignora, salvo alguns cálculos matemáticos [...] Ou seja, somente Deus conhece a verdadeira natureza dos Céus, sua essência, forma, movimentos e causas. Entretanto, Ele deu ao homem o poder de conhecer as coisas sob os Céus, aqui é o

\footnotetext{
9 Vale ressaltar que para os pensadores judeus de orientação mais platônica, como Isaac Israeli e S. Ibn Gabirol, este problema náo se apresenta. São pensadores metafísicos por excelência que não se inserem naquilo que Guttmann denomina filosofia do judaísmo, mas partem das indagações racionais e da temática filosófica, ainda que tenham o judaísmo como pano de fundo.
} 
mundo do homem, esta é a casa que lhe pertence, na qual foi colocado e da qual ele mesmo faz parte [...] É de fato ignorância ou uma espécie de loucura fatigar nossas mentes com questóes que estão fora do nosso alcance, sem a posse dos meios para nos aproximarmos delas. Devemos nos contentar com aquilo que está ao nosso alcance e abandonarmos o que não pode ser alcançado pela inferência lógica, como aconselham aqueles dotados de grande influência divina. (Guia, II, 24).

Outra crítica forte que o pensador judeu oferece em sua obra é aos pensadores do Kalam. Enquanto aqueles, especialmente os adeptos da versão mutazilita, acreditavam ser possível chegar às verdades bíblicas através da especulação racional, Maimônides, seguindo o raciocínio talmúdico apresentado acima, discordava disso veementemente. Os mutakallimin, adeptos de uma teologia altamente racional, defendiam a possibilidade de demonstrar a existência de Deus e atributos intrínsecos como sua unidade, eternidade e incorporeidade por meio de argumentos puramente racionais, bem como acreditavam ter demonstrado a criação a partir do nada também por esta via. Maimônides descarta essa possibilidade afirmando que, na verdade os métodos utilizados por aqueles nada demonstram.

Os métodos utilizados pelos mutakallimin em prol da creatio ex-nibilo já foram por mim descritos e os seus pontos fracos expostos. Assim como as provas de Aristóteles e seus seguidores sobre a eternidade do universo, eles são, na minha opinião, inconclusivos e sujeitos a fortes objeçôes. (Guia, II, 16).

De modo geral, a temática apresentada por Maimônides no Guia dos perplexos não se distancia muito do elenco de preocupaçóes que ocupou a mente dos talmudistas, bem como dos mutakallimin, ainda que sua abordagem seja distinta. O pensamento de Maimônides é profundamente marcado pelo judaísmo rabínico e notamos claramente esta marca ao comparar seus escritos entre si. Do mesmo modo que tenta compatibilizar certas noçóes derivadas do relato bíblico com as teorias filosóficas, no campo da ética, notamos que, por vezes, há paralelos flagrantes entre seus textos religiosos e seus textos filosóficos, como é claramente perceptível em suas exposiçōes sobre a Mishná e certos conteúdos do Guia dos perplexos. Obviamente, a linguagem e o tom utilizados são absolutamente diferentes e a explicação se desenvolve a partir de vocabulários, teorias, argumentos e fundamentaçóes bastante diversos, mas o pensamento inicial que desperta a reflexáo do autor é basicamente o mesmo. 


\section{A QUESTÁo do MAL E SUA RELAÇÁo COM A MATÉRIA}

Para Maimônides, assim como para o pensamento judaico em geral, as questôes éticas são fundamentais e incluem necessariamente a relação com Deus mantida pelo povo judeu. Em virtude disso, em relação à questão específica do mal não ocorrerá de modo diferente: ela será tratada por Maimônides, tanto do ponto de vista ontológico, quanto a partir da ética. Neste texto, apresentaremos o pensamento do autor a partir das visóes que o próprio nos oferece no texto do Guia. Na obra, a questão do mal pode ser dividida nos seguintes aspectos: a idéia sobre o mal em si mesmo como princípio ontológico; a posição do autor sobre o mal natural ou os males que acometem a realidade sensível; e a questão referente ao mal moral; além de suas observaçóes acerca das funçóes da lei divina.

No capítulo 12 da terceira parte de sua obra, Maimônides divide os males em três classes: os males que acometem os homens e os corpos em geral; os males que um homem inflige a outro ou aos demais; e os males que o homem causa a si mesmo. Mas, vale ressaltar que, ainda que o autor assim organize suas idéias sobre o tema, a estrutura do Guia não é disposta como um tratado filosófico sistemático, em virtude do próprio objetivo do autor, conforme já explicamos. Dessa maneira, muitas vezes, estas categorias nas quais estamos dividindo o estudo do mal não aparecem claramente definidas ou delimitadas, mas são expostas de modo interligado, cabendo ao leitor a organização para a exposição.

Quanto à questão do mal em si mesmo, podemos dizer que, da mesma maneira que tantos outros pensadores de sua época, dedicados a elaborar uma conciliação entre a filosofia e as Escrituras, Maimônides não acredita na existência de um mal substancial, enquanto princípio independente ou causa última do mal no mundo. Sob o governo de um Deus que é puro bem e do qual somente o bem pode proceder, o mal é a ausência do bem de Deus, sua falha ou sua deturpação, ocorrendo por algum empecilho à perfeição ou por acidente: "A verdadeira ação divina, em toda sua integridade é o bem, porque é o ser." (Guia, III, 10). Conforme Scholem, a questão do mal é um dos pontos fundamentais que distanciam os filósofos judeus dos místicos, ambos chamados por ele de "aristocratas do pensamento", e isso ocorre sistematicamente através da história. Para Scholem, "em geral, os filósofos do judaísmo tratam o problema do mal como algo sem importância em si mesmo. Alguns deles têm se mostrado mais que orgulhosos dessa negação do mal, considerando-a um dos pilares mestres do que chamam o judaísmo 
racional." Os místicos, ao contrário "têm um forte sentimento da realidade do mal e do escuro horror que há em torno de cada ser vivo. Não procuram, como os filósofos, descartar-se dele por uma fórmula conveniente; procuram antes penetrar em sua profundeza." (SCHOLEM, 1995, p. 37). No caso dos filósofos medievais de orientação aristotélica como Maimônides, esta contraposição é especialmente flagrante na comparação com as preocupações dos cabalistas.

Sem estatuto ontológico próprio, o mal no Guia dos perplexos aparece como meramente privaçáo do bem e, desse modo, devemos passar à primeira classe de males que Maimônides distingue, ou seja, àquilo que podemos chamar de "mal natural", ou aos "males" que acometem os homens e os corpos em geral. Na linha dos aristotélicos e neoplatônicos medievais que, por sua vez, seguiam o conjunto da literatura atribuída a Aristóteles na época, defende que todos os corpos são compostos de matéria e de forma, e que a corrupção e a morte atingem estes corpos exclusivamente em virtude da matéria que os compóe. A forma, considerada em si mesma, não está submetida a esta situação, a não ser acidentalmente, pelo fato de que está unida à matéria, e somente enquanto assim estiver. A forma em si é perene e incorruptível e a nobilíssima forma humana é a imagem e semelhança de Deus (Guia, III, 8) e, caso fosse atingida pela corrupção, isto ocorreria de modo exclusivamente acidental. Assim, Maimônides associa a matéria à privação, à qual está indissoluvelmente ligada, tornando-se assim a origem mesma dos "males" que atingem os corpos. Na parte III do Guia, no capítulo dedicado à matéria, diz que "a verdadeira natureza da matéria implica sua indubitável associação com a privação" (Guia, III, 8), de certo modo complementando aquilo que já expusera sobre a matéria na parte I, ao comparar as idéias bíblicas com as concepçóes dos filósofos, conferindo as devidas diferenças de vocabulário:

Não somente entre os adeptos da Torah, mas também entre os filósofos e sábios dos povos antigos que se pronunciavam sobre os princípios das coisas em termos obscuros e enigmáticos. Assim, Platão e seus predecessores denominavam a matéria "fêmea" e a forma "macho". Já sabes que os princípios dos seres que nascem e perecem são três: a matéria, a forma e a privação particular inerente à matéria, pois, se esta não contivesse em si a privação, não seria suscetível da forma, daí que a privação seja elemento integrante dos princípios. Esta cessa quando advém a forma e uma nova privação a substitui, e assim perpetuamente, como se ensina na física. (Guia, I, 17). 
Maimônides se refere à matéria como uma casada adúltera que, ainda que jamais esteja livre e isenta do vínculo marital com a forma, é infiel, pois não cessa de mover-se a fim de livrar-se da forma atual, buscando constantemente outra forma para substituí-la. Assim, "está claro, a partir disso, que toda destruição, corrupção ou imperfeição se origina da matéria" (Guia, III, 8), e que todos adoecemos e morremos por causa da matéria. Maimônides interpreta uma série de passagens bíblicas que se referem à mulher e seu comportamento pecaminoso, despudorado ou adúltero como alegorias para a situação da matéria e, desse modo, a associaçáo da mulher com o pecado que está presente em inúmeras passagens do Velho Testamento são, a partir desta analogia, explicadas.

A matéria é também entendida como a causa pela qual nossa inteligência não é capaz de ver claramente a si mesma e às verdades superiores. A isso se refeririam as passagens bíblicas que aludem ao véu que nos separa de Deus: "A matéria é um grande véu que impede de ver a inteligência como realmente é [...] por tal motivo, sempre que nossa inteligência aspira ver Deus ou algumas das inteligências separadas, tropeça neste véu interposto entre eles." (Guia, III, 9).

Outra questão que vale ressaltar aqui é aquela de que, dado que Deus é criador de tudo a partir do nada, caberia a objeção interposta por parte de alguns detratores de que, portanto, deva ser Deus o agente causador dos males, uma vez que, necessariamente, é Ele quem confere a matéria aos corpos. Maimônides não só conhece a possibilidade de esta objeção ser levantada, como afirma que, direta ou indiretamente, os mutakallimin acabam por defender esta idéia, uma vez que "asseguram que é Deus quem cega e ensurdece e acalma o que se agita, dado que tais privaçôes, segundo eles, são realidades" (Guia, III, 10). Maimônides contesta estas afirmaçóes, apontando sua inconsistência, como o fim de reafirmar o mal como privação. A privação é, por definição, a inexistência de algo, não podendo ser, portanto, uma realidade em si mesma. A privação não é ser, mas não-ser. Além disso, argumenta no sentido de desvincular o agente da privação, uma vez que é preciso ser para ter um agente. Um não-ser não necessita disto, nem há por que determinar um agente para ele, uma vez que algo que não é não pode ter sido efetivado pela ação de um agente. Para tanto, analisa uma série de situaçôes corriqueiras, e toma como exemplo a idéia comum de que no caso hipotético de um homem que disponha de perfeitas condiçóes para salvar um outro da morte abster-se de fazê-lo, de algum modo, este o matou ou foi responsável por sua morte. Ele discorda desse julgamento e assim explica: 
De qualquer modo, fica claro para ti que em nenhum caso pode a ação de um agente vincular-se à privação e que "efetuar a privaçáo" somente poderá ocorrer por acidente (ou indiretamente) como já expusemos. Por outro lado, o que um agente realiza de modo direto é algo que necessariamente existe, seja qual for o agente e deve se referir à coisa existente. (Guia, III, 10).

A partir disso, entende que mesmo as imperfeições, deformidades, e as enfermidades que possam vir a acometer os corpos, ainda devem sempre ser consideradas no elenco dos bens, uma vez que a coisa existente e realizada se encontra no âmbito do ser, portanto do bem, e aquilo que lhe falta, do não-ser ou privação, não consistindo propriamente uma realidade a ser considerada. Essa é a explicaçáo que o autor fornece à afirmação de que Deus viu ser muito bom tudo quanto havia feito (Gn 1,31). E aponta que até mesmo a morte deva ser entendida como um bem, porque "ainda o ser desta matéria inferior cuja condição pode ser associada à privação, que engendra a morte e todos os males, é, apesar de tudo, também um bem, no sentido da perpetuação da geração e da permanência necessária do ser" (Guia, III, 10). A partir desta ótica, o mal natural é exatamente isto, ou seja, algo indissociavelmente ligado à existência neste mundo, comum a todos e necessário, por estarem todos os seres neste mundo dotados de matéria. Mas, a matéria em si, por ter ser é um bem. Assim, Maimônides considera explicada a primeira classe de males, demonstrando igualmente a ausência de substancialidade do mal, e sua privação de ser em si mesmo.

Apesar de Maimônides acreditar que a maioria dos males advém do próprio homem, a questão da matéria também está relacionada com as duas outras classes de males, a saber, aqueles que um homem inflige a um outro ou aos demais em geral e aqueles que o homem causa a si mesmo. Quanto àqueles males que um homem inflige aos demais, por exemplo, a tirania, Maimônides afirma que estes são pouco numerosos e dificilmente se encontram generalizados e nem são excessivamente frequentes. Quanto àqueles males que cada homem causa a si mesmo, estes são muito mais numerosos e frequentes e praticamente não há homem que se isente deles.

$\mathrm{Na}$ visão do autor, todos os males e condiçôes perniciosas do corpo e da alma encontram sua causa nos vícios e nos apetites desenfreados, seja pela comida, seja pela bebida ou pelo ato sexual, e estes podem ser ocasionados tanto por abuso quanto pela má qualidade. Isto ocorre por duas razóes: a primeira razão é que as alteraçóes que o corpo experimenta afetam necessariamente a 
alma, uma vez que a alma é uma força que reside no corpo e que as propriedades da alma dependem das condiçóes do corpo; dessa maneira, os abusos e vícios cometidos pelo corpo e que alteram diretamente o corpo no plano sensível têm consequências também na alma por estar vinculada a ele. A segunda razão é que, conforme Maimônides, a alma se familiariza com as coisas supérfluas e adquire uma forte disposição para desejar as coisas que não são necessárias para a conservação do indivíduo ou da espécie e esta disposição se torna um hábito. E, para o desejo das coisas supérfluas não há limite. Em virtude disso, a educação moral em direção aos bons hábitos é necessária para que o homem não se desvie de seus propósitos superiores. Esta educaçáo conduz à virtude e afasta do vício. A esta ideia, que, a princípio, parece ser de fundo puramente filosófico e soa como inspirada pelos textos éticos de Aristóteles, faz eco o que o autor expóe no seu Comentário à Mishná, quando nos explica acerca do estabelecimento dos vícios e virtudes na alma:

Saiba que estas virtudes morais e vícios sáo adquiridos e firmemente estabelecidos na alma pela frequente repetição das açôes relacionadas a um hábito moral particular por um longo período de tempo e por tornar-se acostumado com ele. Se estas açóes são boas, adquiriremos a virtude; se elas são más, iremos adquirir o vício. (MAIMONIDES, 1983, p. 68).

Ainda sobre o paralelismo necessário e a ligaçáo entre corpo e alma que não pode ser subestimada ou desconsiderada, Maimônides utiliza a analogia do médico na "cura" das qualidades morais e condução ao bem-estar e saúde da alma: "Se sua alma se tornar doente ele deve seguir o mesmo percurso no tratamento dela que no tratamento médico dos corpos." (MAIMONIDES, 1983, p. 68).

Usando uma analogia comum no pensamento grego, ele sustenta que, assim como um médico que cura o corpo necessita conhecer o corpo que ele está curando, o que são as partes do corpo e quais as coisas que deixam o corpo doente ou saudável, assim também aquele que trata a alma - o "homem sábio" - precisa conhecer a alma em sua totalidade e em suas partes, assim como o que a deixa enferma e o que a deixa saudável. (SHATZ, 2005, p. 172).

Esta analogia não é, de modo algum, novidade na filosofia judaica e já havia sido anteriormente utilizada na por Ibn Gabirol, de modo bem mais explícito e desvinculado de conotaçóes religiosas. Para este autor, o homem ético 
será como o médico hábil que prepara receitas e que toma de cada remédio uma quantidade precisa, de modo que os fármacos sejam diferentes em peso; por exemplo, tomando deste um daniq, daquele outro um qirat e coisas parecidas, levando em conta os efeitos destas quantidades. E esse tal [médico] não estará satisfeito até que acrescente algo [na mistura] que impeça um mal, fazendo tudo isso, com base em um cálculo previsto. (IBN GABIROL, 1990, p. 63).

Mas Ibn Gabirol se revela muito mais naturalista, por assim dizer, do que propriamente racionalista como se apresenta Maimônides. E, pela ausência completa de referências na obra de Maimônides ao texto de Ibn Gabirol, não se pode afirmar que esta analogia tenha sido inspirada pelo seu antecessor. Esta analogia deve ter sido proveniente diretamente do pensamento grego, dos pensadores judeus e muçulmanos que o precederam, ou é simplesmente mera consequência da formação médica do autor.

Vale salientar que, enquanto as semelhanças entre as concepçóes filosóficas e religiosas de Maimônides são sensíveis, existem notáveis diferenças entre suas idéias morais e seus escritos médicos. Não parece haver uma continuidade muito fluida entre estas duas diferentes facetas da obra do autor. Encontramos fortes recomendaçóes constantes do Guia dos perplexos e em suas outras obras de caráter moral quanto ao recato sexual. $\mathrm{O}$ autor ainda reforça a idéia através da expressa recomendação não somente quanto à moderação, mas também quanto à proibição de sequer falar sobre sexo. Isto advém diretamente da tradição judaica, em cujo idioma sagrado, o hebraico, não foram jamais criados termos para a referência às partes sexuais do corpo humano, assim como para as atividades sexuais e, mesmo, as de excreção. Curiosamente, estas consideraçóes morais de Maimônides não condizem, no entanto, com as páginas médicas escritas pelo autor, nas quais podem ser encontrados detalhados registros e recomendaçóes quanto a esta atividade humana.

Parece ficar assim estabelecida uma notável diferença entre o Maimônides eticista-moralista e o Maimônides médico, a julgar por algumas diferenças entre ambas as posiçóes sustentadas pelo autor. É notável que, como moralista, sugerisse evitar falar de temas sexuais e, como médico, em contraposição, promovesse a conversaçáo sobre estes temas como uma forma de estimular o desejo. Também há uma marcante diferença entre as páginas que, sobre a sexualidade, escreveu na Mishné Torah e as que se encontram em suas obras médicas. A Mishné Torah mostra-nos uma posição de mesura, de equilíbrio. As páginas do Tratado sobre o coito, do Regime da saúde e outros textos mais sugerem, ao contrário, uma idéia de 
luxúria e certa falta de limite: os afrodisíacos, as substâncias para massagear o pênis e outras poçóes nos dão a idéia de que a vida sexual de seus pacientes era bastante ativa e ligeiramente promíscua. (BORTZ, 2004, p.99).

Em seu trabalho médico, Maimônides "proporcionou a informação necessária para aumentar o vigor, mas, ao mesmo tempo, recomendou mesura e equilíbrio, fornecendo ao paciente interessado uma explicação racional sobre porque o prazer em excesso poderia prejudicá-lo" (BORTZ, 2004, p. 100). Podemos pensar em diversas razóes para esta aparente contradição, mas cremos que uma possível explicação pode advir da idéia que o autor sustentava de que nem todos os homens são iguais. Desse modo, nada há de anormal em que enquanto moralista defendesse uma posição, mas que, em sua profissão de médico, desenvolvesse técnicas visando o incremento da atividade sexual, a fim de satisfazer os anseios de seus pacientes. Para Maimônides existem diferentes categorias de homens e esta distinção se relaciona com o grau de dedicação e escravidão à matéria e, em contraposição, com o grau de busca da forma, pura e inteligível, bem como da finalidade última do homem. Os homens se distribuem, portanto, ao longo de uma escala que tem seus dois extremos: o inferior é onde se encontram aqueles que são escravos da matéria, separados de Deus por este véu, e que, entregues à gula e à lascívia, se abstêm completamente do pensamento e da reflexão sobre o inteligível. Estes homens vivem imersos na sua animalidade, distante da finalidade propriamente humana. No outro extremo, o superior, encontramos os homens para os quais os incentivos da matéria são repugnantes, feias e imperfeitas:

Principalmente o tato que, como afirmou Aristóteles representa uma coisa vergonhosa para nós e é determinante na nossa apetência pela comida, bebida e ato sexual. É mister, pois, restringir tudo isso, e, na medida do possível retrair-se, arrepender-se de colocá-lo em prática, não falar nem discursar sobre isto nem formar reunióes para tal feito. Mais ainda, o homem deve dominar todos estes impulsos, reduzi-los o quanto possa e ater-se ao indispensável. Deve propor-se como ideal o que é próprio do homem enquanto tal, a saber, a concepção das coisas inteligíveis cujo objeto supremo e mais nobre é compreender, até onde lhe for acessível, a Deus, seus anjos e demais obras. (Guia, III, 8).

Estes são aqueles que Maimônides denomina os homens livres. São os indivíduos que se esforçam sempre em preferir o que há de mais nobre, aspirando à imortalidade, conforme requer a nobreza de sua forma e somente 
pensam na concepção das coisas inteligíveis, em alcançar uma idéia exata do todo e unir-se ao intelecto divino de onde provém sua forma que se infunde sobre eles.

Podemos ver que, desse modo, Maimônides atribui a causa do pecado, em última instância, também à matéria. Não só os males físicos, mas também "todas as faltas e prevaricaçóes humanas são motivadas por sua matéria e não por sua forma, enquanto todas as suas virtudes procedem de sua forma" (Guia, III, 8). Assim, podemos concluir que a disposiçáo racional de controle das paixóes e apetites sensíveis procede da forma, enquanto o próprio apetite advém da matéria.

Por outro lado, a ignorância é do mesmo modo associada com a matéria, uma vez que a própria ignorância, em si mesma, por ser a ausência do conhecimento é também uma privação; em contraposição, a ciência é associada à forma. Em virtude disso, a ignorância é causa de grande parte dos males que os homens infligem a si mesmos e aos demais.

Se estivessem na posse da ciência, cuja relação com a forma humana é comparável à da visão em relaçáo ao olho, sentir-se-iam impedidos de prejudicar a si mesmos e aos demais, uma vez que o conhecimento da verdade freia a inimizade e o ódio e evita que os humanos se prejudiquem mutuamente. (Guia, III, 11).

Isso ocorre principalmente porque, em seu modelo que só admite a matéria corpórea, os seres mais elevados são puras formas e, portanto, substâncias separadas da matéria. Ao adquirir conhecimento, o homem se aparta da matéria e adquire assim o intelecto adquirido - possuído somente pelos humanos.

Seguindo Al-Farabi, Maimonides introduz um tipo de intelecto possuído somente pelos humanos, nomeadamente o intelecto adquirido. Este intelecto adquirido é superior ao intelecto das esferas, já que ele é desprovido de matéria: não é uma faculdade no corpo, mas é "realmente separado do corpo orgânico e transborda sobre ele." (Guia, I, 72; RUDAWSKI, 2010, p. 86).

Cabe acrescentar que, na visão de Maimônides, por consequência, o pecado do homem livre é mais grave do que do escravo, uma vez que o que conduz o escravo ao pecado é a ignorância e os acidentes que atingem sua matéria, em virtude de sua escravidão e animalidade. Os homens virtuosos e 
sensatos conhecem a sabedoria, aceitam a natureza das coisas e os preceitos da Lei e assim contemplam claramente a bondade e a verdade universais. Buscam somente o necessário para a satisfação de suas necessidades corporais.

\section{A questáo da Lei}

Com base no exposto, faltaria abordar ainda a finalidade da Lei. A lei divina contida nas Escrituras, assim como a obrigatoriedade de observância de todos os preceitos judaicos, apresenta, para Maimônides, uma finalidade principal, entendida como o estabelecimento da noção do Deus verdadeiro e a abolição da idolatria (Guia, III, 32) e associada a ela, a conservação da prática que serviria de sustento a esta fé ${ }^{10}$. Por outro lado, com relaçáo à utilidade da lei quanto ao bem-estar humano, apresentaria uma dupla finalidade: o bemestar espiritual e corporal. Este bem-estar está relacionado também à melhoria das relaçóes de uns com os outros:

Isto pode ser atingido por duas vias: primeiro, eliminando a violência recíproca, de modo que cada qual possa proceder a seu arbítrio e conforme suas faculdades, mas sem esquecer da utilidade comum; segundo, inculcando em cada indivíduo uma ética proveitosa para a vida social, orientada para a perfeita regulação dos interesses sociais. (Guia, III, 27).

Estes dois tipos de bem-estar, o corporal e o espiritual, são entendidos também em termos filosóficos, como tipos de perfeição possíveis ao homem:

Efetivamente foi demonstrado que o homem tem a seu alcance dois tipos de perfeição, a primeira perfeição é aquela do corpo, a segunda perfeição é a da alma. O primeiro consiste em gozar da mais saudável condição de suas relaçóes materiais e isso é possível unicamente quando o homem tem todas as suas necessidades supridas, como elas se apresentam; se ele tem sua comida e outras coisas necessárias para seu corpo, quer dizer, vestimenta, banho e afins. Mas um homem sozinho não pode adquirir tudo isso; é impossível para um único homem obter este conforto; isto é possível unicamente na sociedade, uma vez que o homem, como é bem sabido, é, por natureza, social.

10 "Para uma compreensão puramente histórica da religiáo, a análise de Maimônides sobre a origem das mitzvot, os mandamentos religiosos, é de grande importância, mas seria preciso ter coragem para sustentar que sua teoria das mitzvot era tendente a incrementar o entusiasmo dos fiéis pela prática real e aumentar a atração imediata pelo sentimento religioso." (SCHOLEM, 1995, p. 30). 
A segunda perfeição consiste em tornar-se um ser inteligente em efetivo, isto é, ele sabe sobre aquilo que existe tudo o que uma pessoa perfeitamente desenvolvida é capaz de conhecer. Esta segunda perfeição certamente não inclui qualquer ação ou boa conduta, mas somente conhecimento, o qual é atingido pela especulação ou estabelecido pela investigação. (Guia, III, 27).

Como finalidades da Lei, ainda no sentido da perfeição, Maimônides aponta também o abandono de nós mesmos e o desprezo aos apetites, assim como a satisfação com o provimento daquilo que nos é necessário; o estímulo à doçura e à docilidade, à complacência, disciplina e condescendência; a perspectiva de pureza e santidade "consistente em refrear o amor carnal, evitálo e entregar-se a ele o mínimo possível” (Guia, III, 33).

Ainda que o autor aponte a necessidade da sociedade para a consecução dos objetivos que conduzem ao bem-estar corporal, Maimônides não reforça a necessidade da sociedade para a consecução da perfeição da alma. Notamos que a ética do pensador judeu, ao menos no seu extrato superior, ou seja, no que se refere às questôes da alma, não é exatamente uma ética direcionada ao outro, com finalidade social ou de coesão comunitária, mas consiste numa série de prescriçôes destinadas à perfeição de si mesmo ${ }^{11}$. Mesmo que afirme o caráter comum a todos, tanto da lei divina, quanto da lei natural (Guia, III, 34), expóe que a razão disso é que estas devem necessariamente ser destinadas a todos e em conformidade com a busca do bem comum. Ele trata a sociedade como se fosse quase um organismo vivo, que deve trabalhar eficientemente se estiver harmoniosamente ordenado (LEAMAN, 1997, p. 142). Mas a perfeição humana é uma obra individual, na qual o homem deve tomar a Deus mesmo como modelo.

A perfeição última deve ser alcançada mesmo por um indivíduo solitário sem conexóes sociais [...] Assim como a perfeição de Deus não depende de qualquer coisa fora d'Ele mesmo, assim, também a pessoa aperfeiçoada é um agente autossuficiente e sua perfeição última não requer outros para ser atingida. (SHATZ, p. 167).

\footnotetext{
${ }^{11}$ Observem-se aqui as diferenças profundas desta posição em relação à tônica apresentada pela ética judaica contemporânea - que toma corpo especialmente nas formulaçóes posteriores ao nazismo para a qual a constituição do sujeito se define em função do outro.
} 


\section{CONCLUSÁo}

Podemos notar que a proposta moral de Maimônides também não é propriamente decorrente de virtudes em si mesmas e que sejam válidas por si mesmas, mas de uma ética intelectualista. Vale ressaltar que a tradição bíblico-rabínica, não distingue a ética enquanto tal, ou seja, enquanto uma disciplina ou perfeição humana em separado das leis e preceitos religiosos. "Ela não diferencia entre leis morais e leis rituais. Para delimitar claramente a esfera da ética, Maimônides recorre ao ensinamento Aristotélico, conforme o qual "ética" se refere a traços de caráter." (WEISS, 1983, p.3). Profundamente assentado sobre as bases aristotélicas lidas a partir das lentes do racionalismo talmúdico, o autor defende que o objetivo principal do homem é atingir, através da ação moral, uma espécie de perfeição intelectual que conduzirá à compreensão das coisas inteligíveis e, através delas, alçar-se até a iluminação por parte do intelecto divino. Toda a açáo reta e virtuosa do homem, seu comedimento, a necessidade de evitar as paixôes e apetites não possuem um fim em si mesmos, mas têm como objetivo o afastamento da matéria e a identificação com a forma inteligível, perpétua e incorruptível. Esta preparação conduzirá o homem virtuoso que, para Maimônides, é o sábio, à possibilidade de uniáo com o intelecto divino - o Intelecto Agente de Aristóteles e dos filósofos islâmicos medievais. "Ainda que aqui haja uma certa espécie de moralidade que precede e é pré-requisito para a vita contemplativa, há um outro tipo de moralidade que é uma consequência da perfeição intelectual e representa um "transbordamento" ou "emanação" da realização intelectual." (SHATZ, 2005, p. 169).

E não é somente no Guia dos perplexos que Maimônides apresentará esta visão. No Comentário à Mishná, conhecido também como Oito capitulos, vemos a seguinte explanaçáo:

O homem necessita subordinar todas as potências de sua alma ao pensamento, no sentido que referimos no capítulo anterior e direcionar sua visão para um único objetivo: a percepçáo de Deus, quer dizer, o conhecimento d'Ele na medida em que cai sob o poder do homem. (MAIMONIDES, 1983, p. 75).

A conduta virtuosa, a ser atingida a partir da correção do hábito moral e obediência à lei divina é uma disciplina propedêutica que náo apresenta finalidade em si mesma, mas funciona como uma espécie de purificação para atingir uma moralidade superior, que emana diretamente de Deus. Os apetites 
devem ser submetidos à razão e direcionados à busca do conhecimento de Deus, de onde provirá a orientação para a verdadeira vida virtuosa.

O racionalismo exacerbado de Maimônides, que tanto influenciará a filosofia judaica posterior, traz consigo um perigo que é o afastamento da vida comum e a proposição de um objetivo ideal de sábio desvinculado dos anseios e temores humanos mais arraigados. Este excessivo intelectualismo indica que a atitude do seguidor deste caminho deva quase flertar com a ataraxia, distanciando-se tanto dos dramas vívidos que recheiam a Torah e o Tanakh (Antigo Testamento) como um todo, quanto da vida comunitária ativa que sempre caracterizou o judaísmo ${ }^{12}$. Resta saber se esta proposta tem suas raízes exclusivamente na filosofia aristotélica que influenciou o autor, ou se está também perfeitamente consoante com as práticas rabínicas de discussão talmúdica e em algum modelo judaico do sábio (chakham), do piedoso (chassid) ou do justo (tzadik). Até pela extensa aceitação e influência posterior da filosofia maimonideana nos círculos teológicos rabínicos, tendemos a crer que a segunda opçáo talvez seja a mais adequada.

O preço a pagar por esta posição radical da filosofia acabou por ser consubstanciado na incapacidade de despertar o interesse do judeu comum. Assim, no período imediatamente posterior, tomou força a reação dos grupos místicos, especialmente dos diversos tipos de cabalismo, que não ignoravam "aquela região decisiva em que os mortais têm medo da vida e pavor da morte e sobre a qual a filosofia racional nada sabe responder de inteligente" (SCHOLEM, 1995, p. 37). E é nesta região que se encontra também a temática do mal. "Porque é um fraco consolo para aqueles torturados por autênticos anseios e angústia genuína dizer-lhes que seus problemas não são mais que criaçôes de sua imaginação.” (SCHOLEM, 1995, p.37). Frente a este racionalismo exacerbado, que tanta repercussão veio a ter nos meios cultos do judaísmo moderno, não é de espantar a grave perplexidade que acometeu seus filósofos a partir da Segunda Guerra Mundial. Mas, se for olhada a partir de outra perspectiva, talvez não se revele uma proposta superada.

Por isso, hoje, mais do que nunca, apresentam força especial as palavras do médico de Córdoba: "Quem conseguiu tal superfluidade não atingiu nenhuma prerrogativa em sua substância: somente tem uma ilusão falaz ou um brinquedo, nem quem carece de tais superfluidades da vida é necessariamente um deficiente." (Guia, III, 12; TAUSTE ALCOCER, 2004, p. 307).

\footnotetext{
${ }^{12}$ Mais detalhes sobre a polêmica em relação às ideias do Guia que se instalou no período posterior à sua publicação ver Lomba (2004).
} 
Talvez a proposta intelectualista de Maimônides, ao fundamentar o mal na ação humana ignorante e desprovida de lapidação, não esteja tão distante de explicaçóes bem mais modernas como a questão da banalidade do mal, tão brilhantemente descrita por Hannah Arendt. Mas, esse assunto por si demandaria, com certeza, um segundo artigo.

CAVALEIRO DE MACEDO, C. C. Evil, matter, and the Law in Maimonides. Trans/ Form/Ação, Marília, v. 42, p. 171-192, 2019. Ediçâoo Especial.

\begin{abstract}
Moses Maimonides (1135-1204) is one of the most important medieval thinkers. His philosophical work, The Guide for the Perplexed, has not only became a fundamental reference for Jewish thinkers up to the present day, but it also exerted a strong influence on Latin philosophers during the Scholastic period. The Guide covers several themes, and among them is the issue of evil. Maimonides does not believe in the existence of a substantial evil. Evil does not have ontological status and is merely the privation of good. It can be divided into three types: natural evil, the evil that a man imposes on others, and the evil that a man causes to himself. This article intends to explain Maimonides' rationalistic approach to the question of evil and its grounding in matter, the importance of Jewish Law, as well as the notion of ethical conduct that follows from this approach.
\end{abstract}

KEYwORDs: Maimonides. Evil. Matter. Law. Ethical intellectualism.

\title{
REFERÊNCIAS
}

BORTZ, J. Maimónides: medicina preventiva y psicosomática. Buenos Aires: Editorial Sefarad 92, 2004.

CAVALEIRO DE MACEDO, C. C. Um órfāo na ilha deserta: a crítica de Maimônides a Aristóteles quanto à eternidade do mundo. Revista Pandora Brasil: Aristóteles, São Paulo, n. 13, 2009.

GUTTMANN, J. A filosofia do judaísmo. São Paulo: Perspectiva, 2003.

IBN GABIROL, S. La corrección de los caracteres. Introducción, Traducción y notas, Joaquín Lomba Fuentes. Zaragoza: Universidad de Zaragoza, 1990.

IVRY, A. The Guide and Maimonides: philosophical sources. In: SEESKIN, K. The Cambridge Companion to Maimonides. Cambridge: Cambridge University Press, 2005. p. 58-81.

KRAEMER, J. Moses Maimonides: an intellectual portrait. In: SEESKIN, K. The Cambridge Companion to Maimonides. Cambridge University Press, 2005. p. 10-57. 
LEAMAN, O. Moses Maimonides. Surrey: Curzon Press, 1997.

LOMBA, J. Las disputas en torno a Maimónides. In: Maimonides y el pensamiento medieval: VIII Centenario de la muerte de Maimónides. Granada: Universidad de Granada, 2004. p. 37-54.

MAESO, Estudio preliminar. In: MAIMONIDES, M. Guía de perplejos. Edição e tradução: David Gonzalo Maeso. Madrid: Editorial Trotta, 2008. p. 15.

MAIMONIDES, M. Dalalat al-Hairin: The Guide for the Perplexed. Tradução do original árabe por M. Friedlander. NY: Dover Publications, 1956.

MAIMONIDES, M. Guia de perplejos. Edição e tradução: David Gonzalo Maeso. Madrid: Editorial Trotta, 2008.

MAIMONIDES, M. Guia dos perplexos: obra completa. Tradução: Yosef Flavio Horwitz. Revisão técnica Iossi Katri. Sáo Paulo: Sêfer, 2018.

MAIMONIDES, M. Ethical writings of Maimonides. Introduction by Raymond L. Weiss. New York: Dover Publications, 1983.

RUDAWSKI, T. Maimonides. West Sussex: Wiley-Blackwell, 2010.

SCHOLEM, G. As grandes correntes da mística judaica. São Paulo: Perspectiva, 1995.

SEESKIN, K. Maimonides on the origin of the world. Cambridge: Cambridge University Press, 2005.

SHATZ, D. Maimonides: moral theory. In: SEESKIN, K. The Cambridge Companion to Maimonides. Cambridge: Cambridge University Press, 2005. p. 167-192.

TAUSTE ALCOCER, F. El mal según Maimónides. In: Maimonides y el pensamiento medieval: VIII Centenario de la muerte de Maimónides. Granada: Universidad de Granada, 2004. p. 301-307.

VERZA, T. M. A doutrina dos atributos divinos no Guia dos perplexos de Maimônides. Porto Alegre: EdiPUCRS, 1999.

WEISS, R. L. Introduction. In: MAIMONIDES, M. Ethical writings of Maimonides. Introduction by Raymond L. Weiss. New York: Dover Publications, 1983. p. 3.

Recebido: 30/12/2019

Aceito: 30/12/2019 